\title{
An unusual paleokarst sedimentary rock in the Bohemian Karst (Czech Republic), and its regional tectonic and geomorphologic relationships
}

\author{
Karel ŽÁK, Petr Pruner, PAVEl BosÁK, MARCELA SVOBOdoVÁ \& STANISLAV ŠLECHTA
}

\begin{abstract}
An unusual type of paleokarst carbonate sedimentary rock has been found in the Bohemian Karst, Czech Republic. This well-layered coarse-crystalline limestone is reddish in color and occurs as horizontal or slightly inclined layers filling deep paleokarst cavities within karstified faults in Early Devonian marine-limestone host rocks. Field observations confirm that these sedimentary rocks are undoubtedly younger than the polyphased Variscan folding. Petrographic and geochemical studies indicate that the studied paleokarst limestone is quite different from the Silurian and Devonian limestones, from common cave speleothems, as well as from the typical clastic Late Cretaceous and Cenozoic karst sediments of the Bohemian Karst. Carbonate $\delta^{13} \mathrm{C}$ and $\delta^{18} \mathrm{O}$ stable isotopic ratios of the paleokarst limestone $\left(\delta^{13} \mathrm{C}\right.$ from -4.0 to $-6.2 \%, \delta^{18} \mathrm{O}$ from -6.2 to $-8.4 \%$ PDB), differing both from marine Silurian and Devonian limestones and Cenozoic secondary cave carbonates of the area, correspond to a non-marine depositional environment. The paleomagnetic data suggest that magnetic properties of the studied rocks were acquired during the Early to Middle Triassic, although these ages have not yet been confirmed by finds of contemporaneous microfossils. The only microfossils that were extracted using dissolution methods consist of several younger plant and faunal remains including angiosperm pollen grain specimens belonging to the family Myricaceae, likely Tertiary in age. Their sporadic occurrence is interpreted as the result of secondary infiltrations into the millimeter-wide cracks and cavities, in correspondence with the thin-section data on diagenetic successions. Key words: Prague Synform, paleokarst sedimentary rocks, Triassic, paleomagnetic study, $\mathrm{C}$ and $\mathrm{O}$ stable isotopes, plant microfossils.
\end{abstract}

ŽÁK, K., Pruner, P., BosÁk, P., SvobodovÁ, M. \& Šlechta, S. 2007. An unusual paleokarst sedimentary rock in the Bohemian Karst (Czech Republic), and its regional tectonic and geomorphologic relationships. Bulletin of Geosciences 82(3), 275-290 (14 figures, 4 tables). Czech Geological Survey, Prague. ISSN 1214-1119. Manuscript received February 28, 2007; accepted in revised form June 20, 2007; issued September 30, 2007. • DOI 10.3140/bull.geosci.2007.03.275

Karel Žák, Institute of Geology AS CR, v.v.i., Rozvojová 269, 16500 Praha 6-Lysolaje, Czech Republic; zak@gli.cas.cz• Petr Pruner, the same address; pruner@gli.cas.cz・Pavel Bosák, the same address, and Karst Research Institute SRC SASU, Titov trg 2, 6230 Postojna, Slovenia; bosak@gli.cas.cz・Marcela Svobodová, the same address; msvobodova@gli.cas.cz・Stanislav Šlechta, the same address; slechta@gli.cas.cz

A new type of paleokarst infilling was found in the Bohemian Karst, a small karstic region located SW of Prague (Fig. 1). Occurrences of this new type of sedimentary rocks are related to steeply-dipping NW-SE trending karstified faults. These sedimentary rocks are found filling cavities within faults and are either breccias or red limestones. From direct geological observations (folded and steeply dipping Devonian limestone vs. sub-horizontally layered paleokarst limestones), it is evident that studied rocks were formed after the Variscan folding (Fig. 2). These sedimentary rocks are notably different from both usual speleothems and abundant Late Cretaceous to Cenozoic clastic sediments typical within this karstic region. They also differ from Devonian neptunian dikes of the area (described, e.g., by Chlupáč 1996). To clarify age as well as genetic and geomorphologic relationships the paleokarst sedimentary rocks were studied using observation in the field, and in the laboratory on collected samples, including petrological, paleomagnetic, micropaleontological, and stable isotopic geochemical methods.

\section{Field relationships and regional positions}

The Bohemian Karst is developed within the folded and faulted Silurian and Devonian limestones of the Prague Synform, a NE-SW trending sedimentary basin with a complex internal structure (Fig. 1). A general review of the stratigraphy and sedimentology of the Prague Synform was presented by Chlupáč et al. (1998). An alternative view of 


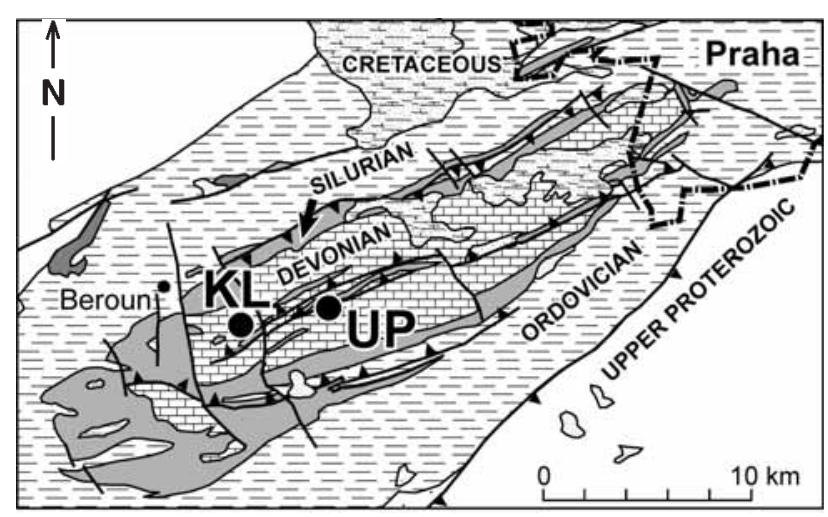

Figure 1. Position of the studied localities Únorová propast Chasm (UP) and Kruhový lom Quarry (KL) within the Prague Synform. Simplified map after Chlupáč et al. 1998. Lithological characteristics of individual units shown in the map: $\bullet$ Neoproterozoic basement: clastic sedimentary rocks (shales, graywackes, locally conglomerates), silicites, submarine basic and intermediate volcanic rocks. Prague Synform: Ordovician dominantly clastic sedimentary rocks (mostly shales, siltstones, sandstones), basic volcanic and volcano-sedimentary rocks; Silurian - clastic sedimentary rocks (mostly black shales), basic volcanic and volcano-sedimentary rocks, limestones; Devonian - in Lower Devonian limestones, in Middle Devonian partly clastic sedimentary rocks (siltstones, sandstones). Platform rocks: Cretaceous - sandstones, marls. Unconsolidated sediments: continental Tertiary sands and gravels (small patches dotted in the map). $\bullet$ The thick angular dot and dash line in the NE map corner shows limits of the town of Prague.

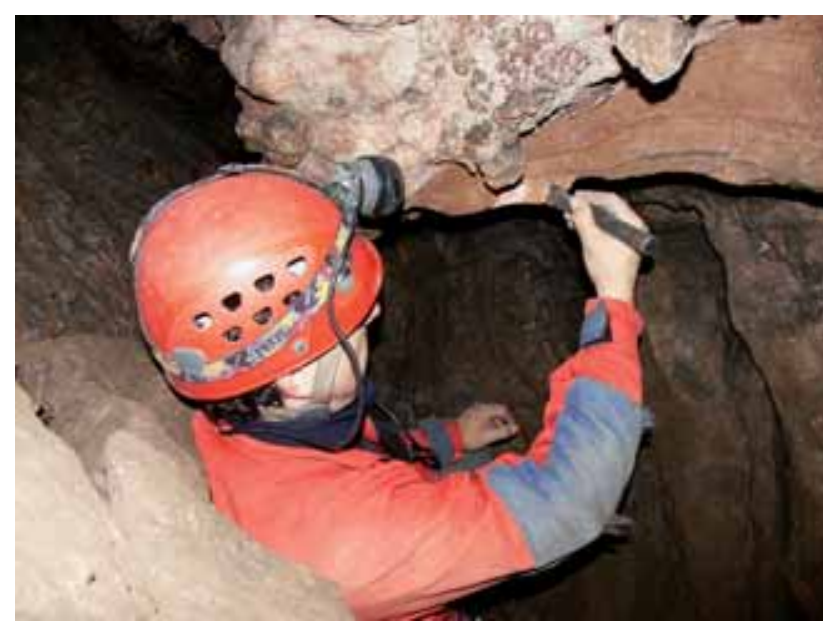

Figure 2. A sampling of the red paleokarst limestone in Únorová propast Chasm. Vertical bedding of the hosting Devonian Kotýs Limestone is well defined by selective corrosion. Sampled red carbonate sedimentary rocks are sub-horizontal. Photo by O. Jäger.

the tectonic structure was published by Melichar \& Hladil (1999) and Melichar (2004), and a detailed structure of the studied area is contained in papers by Svoboda \& Prantl (1950, 1955).

Karstic features within the Paleozoic limestones of the Prague Synform have evolved from the Devonian through to the Quaternary (Bosák 1985, 1997, 1998). Most of the surface and subsurface karstic features developed during the Late Cretaceous and Cenozoic. Manifestations of karstification prior to the Late Cretaceous are rare and almost no specific information about the evolution of the karst is available for most of the Permian, Triassic and Jurassic periods (Turnovec 1980; Bosák 1985, 1997, 1998).

The described carbonate paleokarst sedimentary rocks, which represent a new sedimentary rock type for the Bohemian Karst region, were discovered at two localities. The first locality is represented by the Únorová propast (UP) Chasm NW of Morrina and the second by Kruhový lom (KL) Quarry between Tetín and Srbsko (see Fig. 1). Both localities are located approximately $25-30 \mathrm{~km} \mathrm{SW}$ of Prague.

\section{Únorová propast Chasm}

This vertical cave is located $2 \mathrm{~km} \mathrm{NW}$ of Mořina in the central part of the Prague Synform. The chasm is crosscut at two depth levels [ $4^{\text {th }}$ gallery level, elevation $351 \mathrm{~m}$ above sea level (a.s.1.); $5^{\text {th }}$ gallery level, $332 \mathrm{~m}$ a.s.1.] by underground galleries connecting the limestone pit quarries, operating here since 1891 . The upper and very narrow part of the chasm is capped with limestone blocks and has no open communication with the surface. Today the chasm is located almost directly below the Lomy Mořina mining yard. Access is difficult and requires rappelling down $60 \mathrm{~m}$ of the Trestanecký Lom Quarry to the $4^{\text {th }}$ level gallery opening in the quarry wall. Once in the gallery, a $220 \mathrm{~m}$ traverse in the SW direction leads to the intersection of the gallery and the chasm.

Members of the Speleological Club of Prague performed the first detailed survey of the UP Chasm in 1978, when climbing the natural cavities between the $4^{\text {th }}$ and $5^{\text {th }}$ gallery levels (Lysenko 1978; Havlíček \& Urban 1979, 1984; Havlíček et al. 1980). The deeper part of the chasm (partly including the 5th gallery level) is flooded. Further extension of the known dry section of the cave by speleological group "Vertikála" was done in 1985. Diving exploration was performed in 1981 (Hovorka 1982) and 1985 by divers of the Geospeleos Caving Club. Kolčava (2004) reviewed the exploration history and published new maps and vertical crosscuts of the chasm.

A dry section is defined by tall and narrow vertical cavities while a flooded section is much wider (Fig. 3). The chasm follows faulting in a NW-SE direction, which displays evidence (tectonic disturbance of studied paleokarst sediments) of repeated tectonic movement. The known vertical extent is $64 \mathrm{~m}$ (16 m of which is flooded) while in the horizontal direction the dry cavities are up to $30 \mathrm{~m}$ long and up to $2.5 \mathrm{~m}$ wide. The strike direction of the dominant vertical fault zone is between 115 and $125^{\circ}$ with an average direction of $118^{\circ}$ (Kolčava 2004, Havlíček \& Urban 1984). The dip of the fault zone is vertical. 


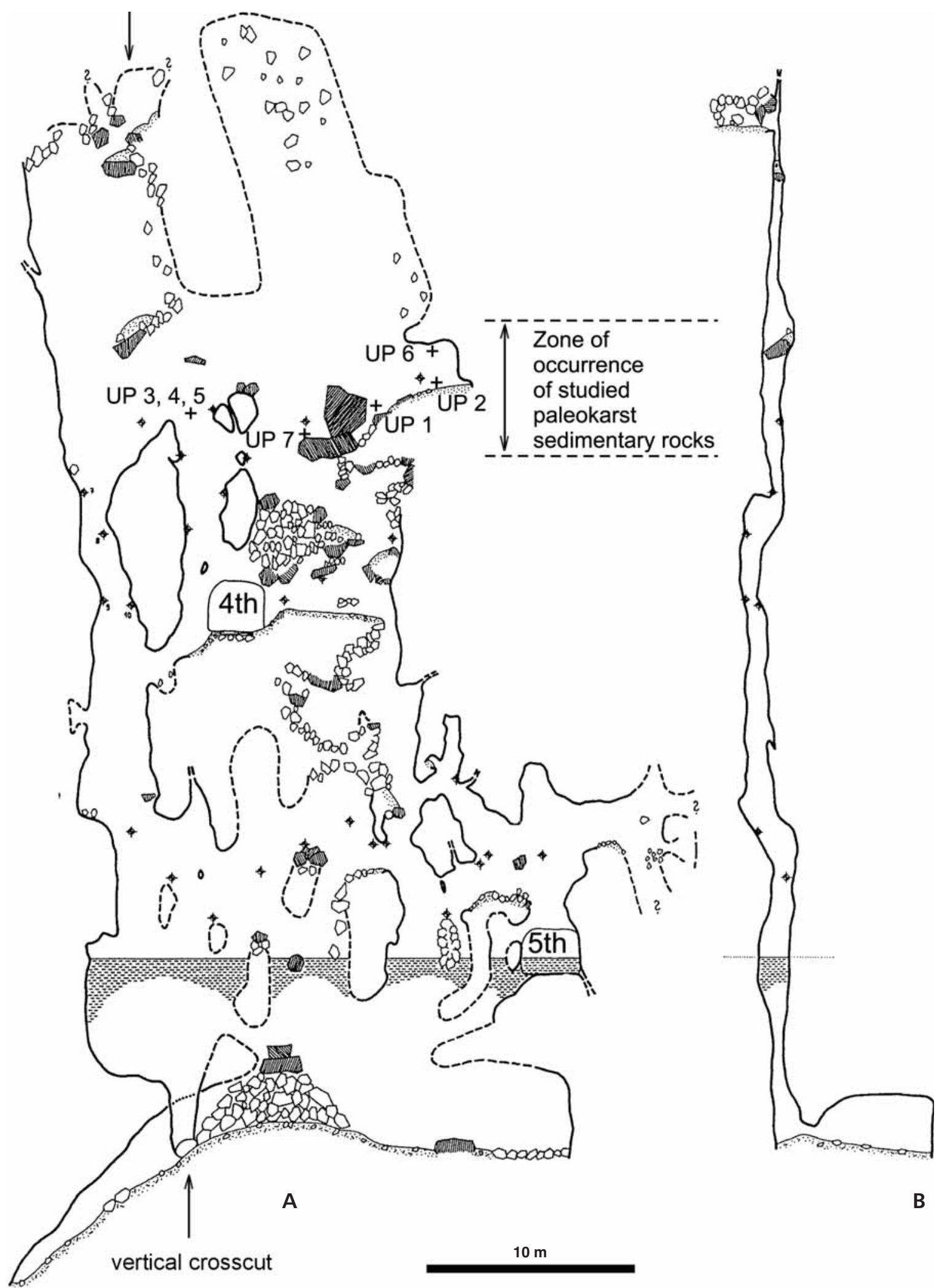

Figure 3. Vertical section of the cavities of Únorová propast Chasm. The positions of paleokarst filling samples taken within the chasm are labeled. The positions of mapping points fixed in the chasm are also shown as small crossed circles. $\bullet$ A - longitudinal vertical profile along the main direction of the cavity. $\bullet$ B - vertical crosscut (position of which is shown in A). Stippled region towards the base of A and B represent a recently flooded zone within the chasm. The crosscuts of the chasm by two gallery levels $\left(4^{\text {th }}, 5^{\text {th }}\right)$ are also shown. Section modified after Kolčava (2004). 


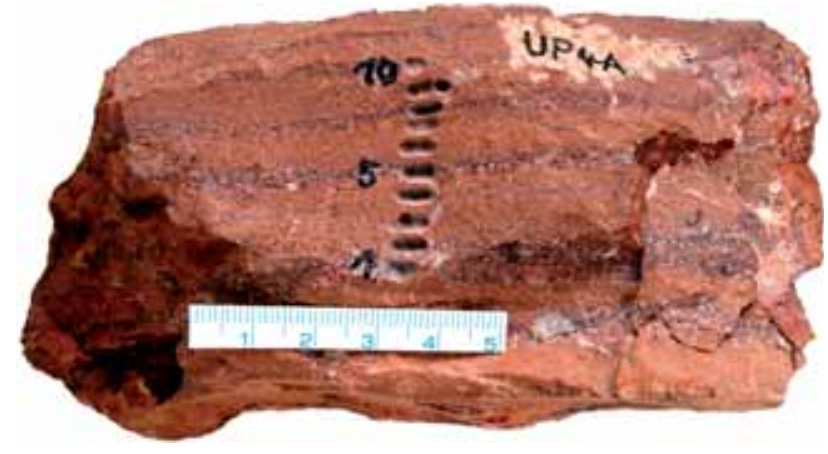

Figure 4. Typical sample UP4A with stable isotope specimen sampling points identified. The sample shows typical alternation of coarse-grained and fine-grained layers. Photo by J. Brožek.

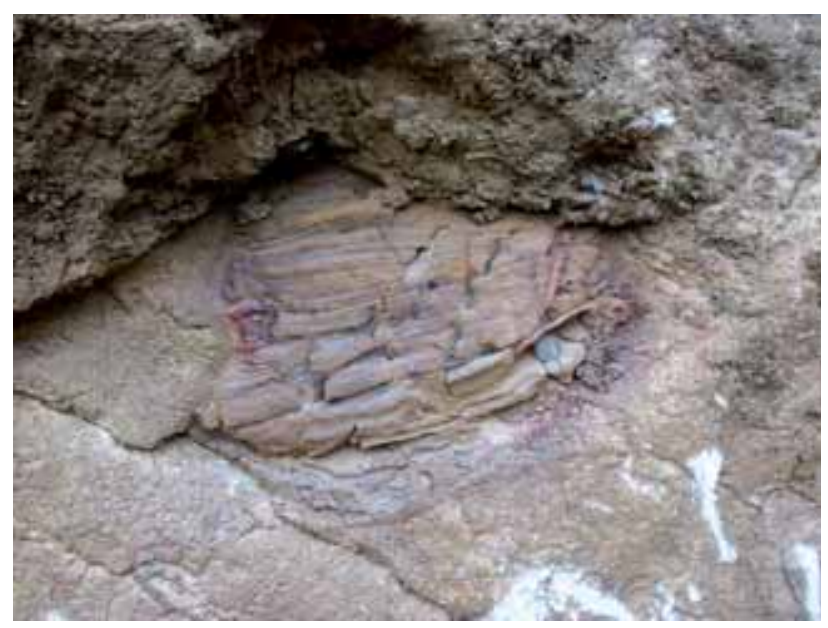

Figure 5. Red carbonate paleokarst filling in the Kruhový lom Quarry. Photo by $\mathrm{O}$. Jäger. The filling in a cavity on the fault is $40 \mathrm{~cm}$ long and $30 \mathrm{~cm}$ thick.

The chasm is formed in the almost vertically dipping, well-bedded Devonian Kotýs Limestone (strike about $65^{\circ}$, dip $80-90^{\circ}$ to SSE), which contains abundant chert concretions. The concretions are usually arranged along the bedding planes and are strongly variable in shape. In addition, concretions are frequently exposed by limestone solution and these protrude out of the cave walls. The fault zone and the chasm obliquely crosscut the limestone bedding planes.

\section{The discovered paleokarst fillings of the UP Chasm}

The newly discovered paleokarst filling occurs in the upper part of the chasm, mostly at an elevation of $c a 365 \mathrm{~m}$ a.s.1., that is above the crosscut by the $4^{\text {th }}$ gallery level. The paleokarstic sedimentary rocks are represented by red-colored, layered limestones, and by well-petrified breccias, frequently of reddish color. The breccias are dominated by fragments of chert and of the host Devonian li- mestone (fragment size from several $\mathrm{mm}$ to $\sim 20 \mathrm{~cm}$ ) and show no layering. Well-bedded red limestone with variable content of clastic component is locally seen overlaying the breccia, while at other sites breccias overlie the red limestone. Locally also the breccias transform into red limestone with clastic admixture, by a decrease in breccia fragment size. In some places the layered limestones occur also inside of breccia cavities. This red paleokarstic limestone displays horizontal to sub-horizontal layering with a clear angular discordance to the host Devonian Kotýs Limestone. Paleokarst limestone layers are up to $30 \mathrm{~cm}$ thick and are up to several meters long (see Fig. 2). The position of the samples taken within the chasm longitudinal cut can be seen in Fig. 3. Cyclic sedimentation with alternating coarse- and fine-grained carbonate layers can also be observed in some sections (see Fig. 4). The studied paleokarst fillings have been disturbed by tectonic movements (some synchronous with their deposition) and affected by later stages of karstification.

In an earlier study of the UP Chasm, Havlíček \& Urban (1984) mentioned these unusual rocks in the following way: "The chasm itself ( $221 \mathrm{~m}$ from the gallery entrance) is developed along huge transverse joint... up to $2.5 \mathrm{~m}$ wide, filled partly by breccia of crushed reddish limestone with fragments of red chert. Red-brown limestone around this fault has a somewhat sandy character." This red limestone is the main subject of this study.

\section{Kruhový lom Quarry near Srbsko}

The extensive KL Quarry, located $1 \mathrm{~km} \mathrm{NW}$ from the Srbsko village (see Fig. 1 for location), has operated here continuously since the second half of 19th century. The main focus of the quarrying is Devonian (Pragian) limestones. The whole Devonian limestone sequence in the quarry is inclined at $c a 25^{\circ}$ to the NW.

\section{The discovered paleokarst fillings of the KL Quarry}

A red paleokarst limestone was discovered infilling a minor cavity within a vertical fault on a wall in KL in November 2004 (fault strike of $130^{\circ}$ ). The filling was expressed as thinly-bedded red limestone, which is macroscopically quite similar to the red paleokarst limestone discovered at UP. As with UP, this red paleokarst limestone postdates the Variscan folding. While the layers of the host Devonian Loděnice Limestone are inclined to the NW (strike about $60^{\circ}$, dip $25^{\circ}$ to $\mathrm{NW}$ ), the layering of the paleokarst infilling was sub-horizontal with a minor SE slope (dip $5^{\circ}$, see Fig. 5). The infilling was $30 \mathrm{~cm}$ thick and $40 \mathrm{~cm}$ long and occurred on the uppermost quarry level at an elevation of 

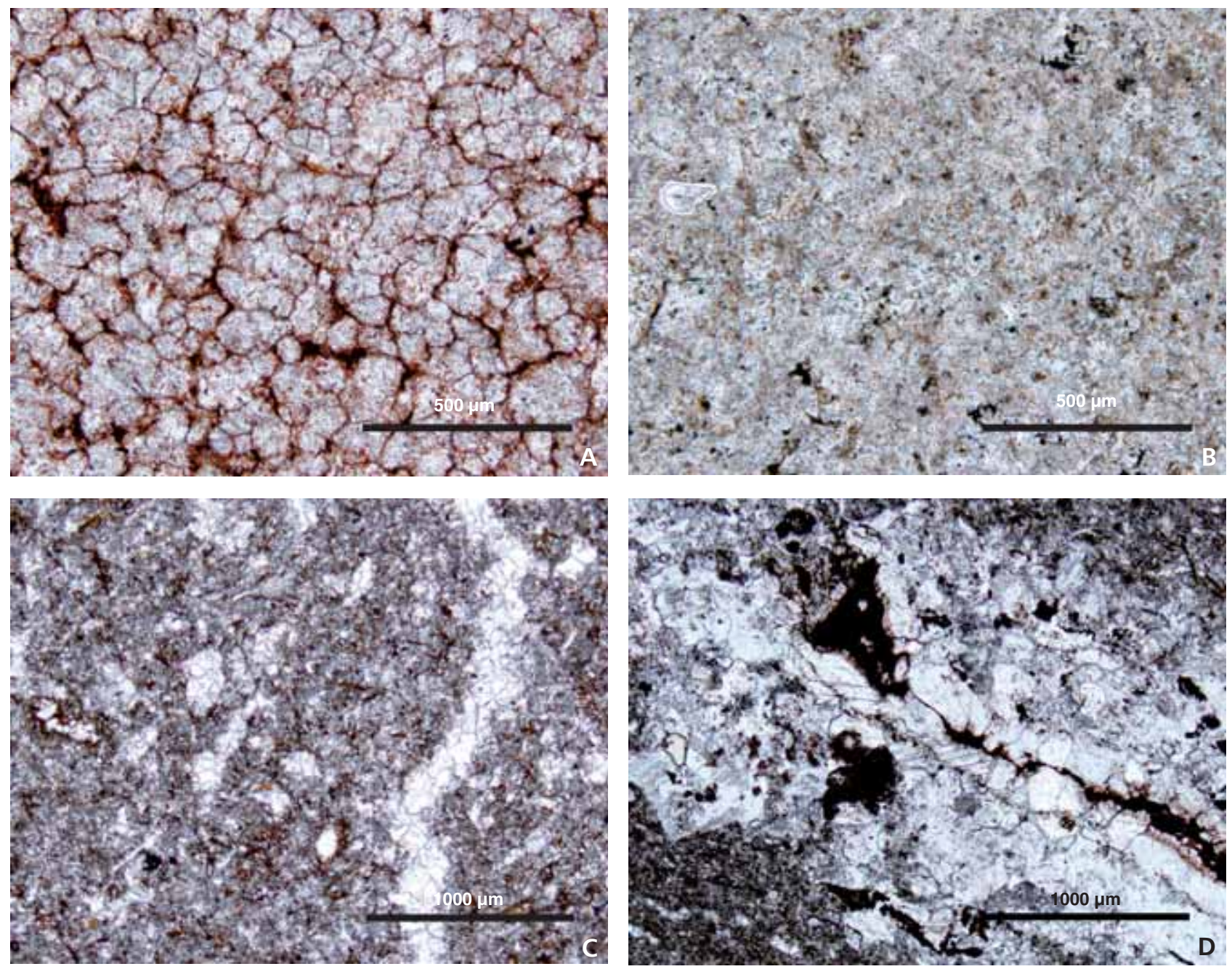

Figure 6. Microphotographs of thin sections of the studied carbonate rocks (photo by P. Bosák, M. Filippi). • A - saccharoidal mosaic of recrystallized grains with ferruginous pigment in intergranular spaces. Polished section No. 911, parallel nicols. • B - recrystallized carbonate rock with rhombohedral-like darker shadows. Fine porosity filled with ferruginous pigment. Note fossil remain (ostracode) in the left part of the figure. Polished section No. 913, parallel nicols. • C - irregularly recrystallized carbonate rock with small fenestral structures (birds eye-like; possibly rests of fossils) and with tiny calcite veinlet. Polished section No. 912, parallel nicols. $\bullet$ D - epigenetic zonal calcite vein with ferruginous pigment. Note euhedral grains and elongated fragments (Devonian fossils?) within the rock matrix. Polished section No. 71, parallel nicols.

$266 \mathrm{~m}$ a.s.l., about $50 \mathrm{~m}$ south of the entrance of Zdenina Cave (Živor et al. 2002). Both the paleokarst filling and the entrance of Zdenina Cave were destroyed by quarrying in early 2005 , before the authors were able to perform detailed sampling.

\section{Field and laboratory methods}

A total of 11 samples of paleokarst carbonate filling were collected during this study (UP Chasm: UP1, UP2, UP3, UP4A, UP4B, UP 4C, UP 5A, UP 5B, UP 6, and UP 7 breccia; KL Quarry: KL-1). Orientation of samples in the field was done using a geological compass (precision $\pm 2^{\circ}$ ). All samples collected at UP Chasm displayed horizontal or subhorizontal bedding-planes (no correction for tilting was applied during the paleomagnetic study).

\section{Micropaleontology}

One representative sample from the limestone was prepared (sample UP4B, dissolved sample quantity about $0.5 \mathrm{~kg}$ ). The residue was not sieved in order to obtain the maximum amount of organic-walled remains. Palynological preparations were conducted using standard acid treatment procedures $(10 \% \mathrm{HCl}, 40 \% \mathrm{HF}$, acetolysis, $30 \%$ $\mathrm{HNO}_{3}$ ) in the laboratories of the Czech Geological Survey in Prague (technique after Wood et al. 1996). Slides were studied with an Opton light microscope. 

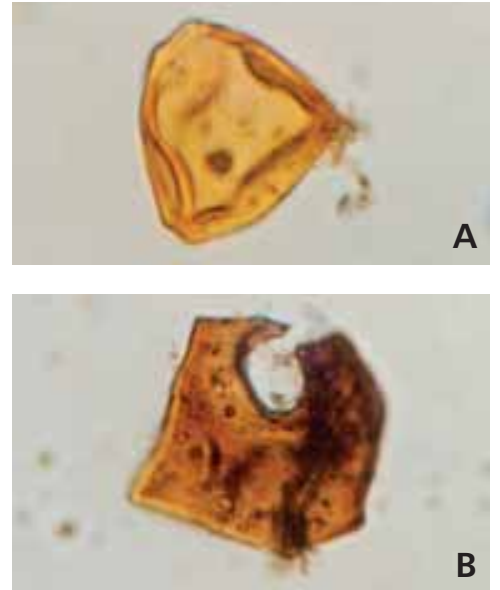
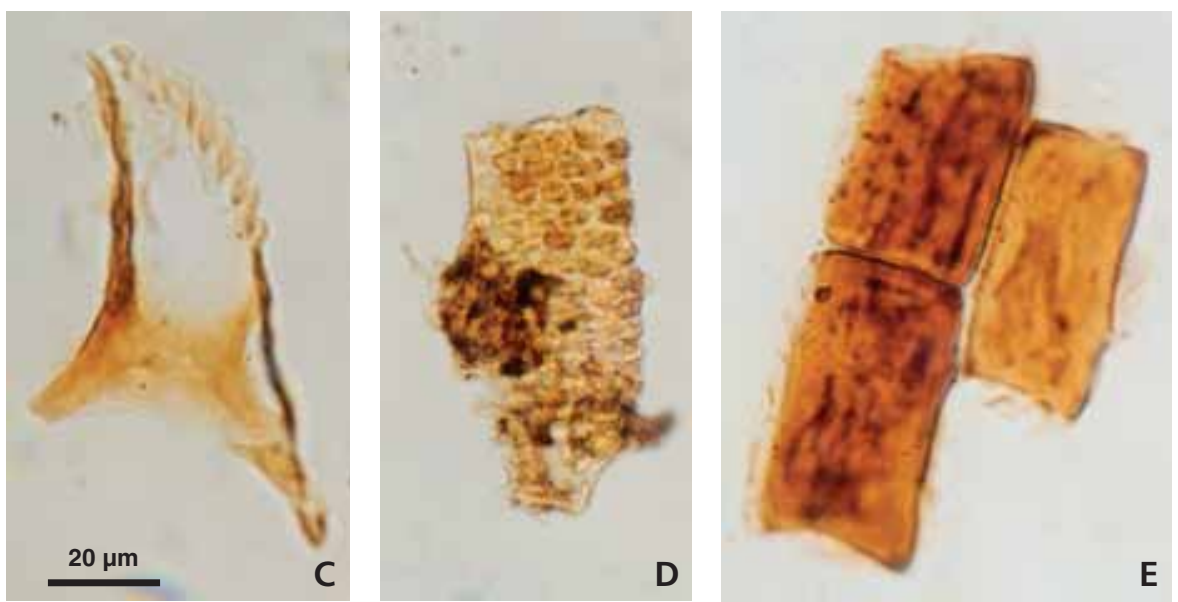

Figure 7. Plant microfossils. $\bullet A$ - pollen grain of Myricaceae. $\bullet B, D, E$ - plant phytoclasts; B - portion of what is likely conifer tracheid, D - portion of vessel elements with pitting, $\mathrm{E}$ - plant phytoclast. $\bullet \mathrm{C}$ - scolecodont. Photomicrographs by M. Svobodová. Scale of all specimens is identical (scale bar in the part C).

\section{Paleomagnetic methods and sample processing}

Laboratory procedures were selected in order to allow the separation of the characteristic components of remanent magnetization (ChRM) and to determine their geologic origin. Oriented field samples were cut into cubes $(20 \times 20 \times$ $20 \mathrm{~mm}$ ) in the laboratory. A total of 10 samples (UP1, UP2, UP3, UP4A, UP4B, UP 4C, UP 5A, UP 5B, UP 6; KL-1) were cut into 22 laboratory specimens, with samples UP4 and UP5 each being cut into 7 specimens resenting different horizontal plains.

For each sample the natural remanent magnetization (NRM), magnetization after alternating field (AF) and thermal demagnetization (TD), as well as volume magnetic susceptibility were measured using JR-5A or JR-6A spinner magnetometers and a KLF-4A Automatic Magnetic Susceptibility Meter (Jelínek 1966, 1973; see also Hrouda et al. 2006). A LDA-3 demagnetizer was used for the AF demagnetization of several pilot samples with a peak demagnetization field of $100 \mathrm{mT}$. Progressive thermal demagnetization employed the MAVACS demagnetizer (Př́hoda et al. 1989).

Phase or mineralogical changes of magnetically active (mostly Fe-oxides) minerals frequently occur during TD, especially at low temperature intervals. To monitor these changes magnetic susceptibility (MS) was measured after each thermal step and plotted normalized to the initial MS measurement as a function of temperature. MS was measured on an Automatic Magnetic Susceptibility Meter KLF-4A (an apparatus based on principle published by Jelínek 1973). The multi-component analysis of Kirschvink (1980) was applied to separate ChRM components. The statistics of Fisher (1953) were employed for the calculation of mean directions of the pertinent RM components derived by the multi-component analysis.

\section{Stable isotopes}

The carbonate from all samples is represented by calcite. Samples of rock were crushed, pulverized in an agate mortar, and treated in a vacuum with $100 \% \mathrm{H}_{3} \mathrm{PO}_{4}$ at $25^{\circ} \mathrm{C}$ (McCrea 1950). Younger veinlets and void fillings were avoided during the sampling. The measurement of $\mathrm{C}$ and $\mathrm{O}$ isotopic compositions of the resultant $\mathrm{CO}_{2}$ gas was performed using a Finnigan MAT 251 mass spectrometer in the Laboratories of the Czech Geological Survey in Prague (I. Jačková and B. Čejková operators). Results are displayed using the usual $\delta$ notation against international PDB standard in \%o. Overall analytical uncertainty was $\pm 0.1 \%$ for both $\delta^{13} \mathrm{C}$ and $\delta^{18} \mathrm{O}$ values.

\section{Results}

\section{Petrography}

Thin sections of the limestone at both localities (1 from KL, 4 from UP) indicate that the samples are composed of sparite ( 0.01 to $0.08 \mathrm{~mm}$ in size) and represent a very unusual, highly irregularly recrystallised, petrologic type (Fig. 6). The sparite (calcite) grains are sometimes seen with an irregular outer rim and darker core while some grains are composite ( 2 to 5 smaller grains). Some grains contain twin-lamellae while other grains are oval or polyhedral in shape. Intergranular spaces are composed of brownish-red impurities (mostly limonite-like material). The mosaic of calcite grains is close to equigranular but prevailing patches of recrystallization stress the pseudo-brecciated texture. In some places, quite large rhombohedra express shadows as indistinct rims built of impurities. Small fenestral textures (birds-eyes) can represent recrystallized fossils 

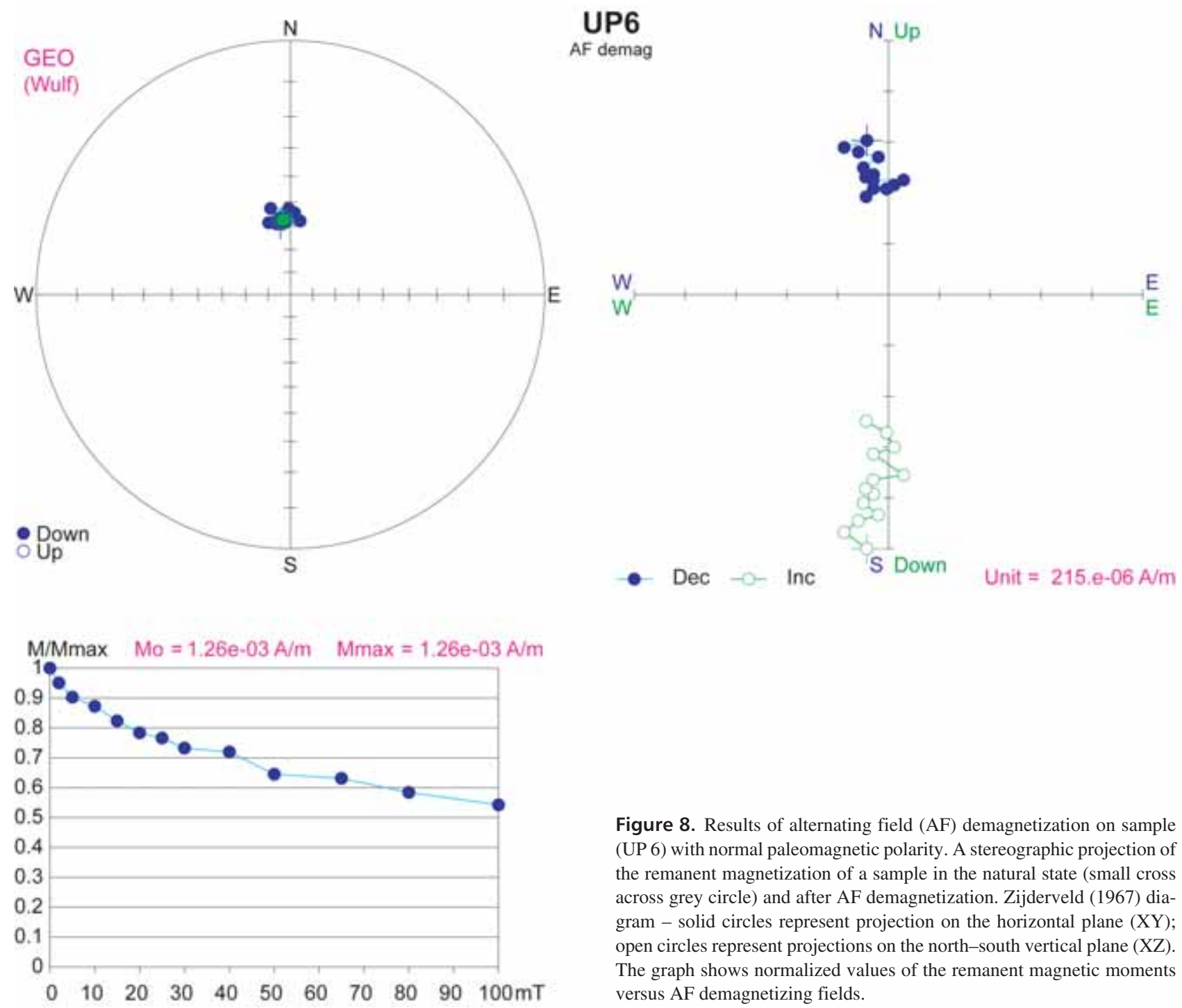

Figure 8. Results of alternating field (AF) demagnetization on sample (UP 6) with normal paleomagnetic polarity. A stereographic projection of the remanent magnetization of a sample in the natural state (small cross across grey circle) and after AF demagnetization. Zijderveld (1967) diagram - solid circles represent projection on the horizontal plane (XY); open circles represent projections on the north-south vertical plane (XZ). The graph shows normalized values of the remanent magnetic moments versus AF demagnetizing fields.

and in some samples ghosts resembling remains of highly recrystallized fossils are observed. In one sample the rock was composed of lithoclasts showing the same rock type as the matrix. Thin calcite veins were observed in some lithoclasts and some of the clasts contain recrystallized fossils released through weathering from the Devonian limestones. Such fossils also form individual clasts. Tiny fragments of plant tissues and what are likely small seeds also occur. Small grains of framboidal pyrite are present but are rare, as is a clastic terrigenous material, which appears as silt-sized elongated grains of quartz $(0.01-0.06 \mathrm{~mm})$ and small flakes of micas (muscovite?). Hypergenic alteration resulted in the formation of corrosional voids, the walls of which are sometimes expressed by concentrated impurities and coated by pure sparite impregnated by organic matter. These voids are mostly filled with a monocrystal of calcite and are interconnected by fine calcite veins causing irregular recrystallization in the closest surroundings.

A XRD determination on the insoluble rock residue (limestone sample slowly dissolved in $\sim 1 \% \mathrm{HCl}$ ) indicates quartz as the main mineral of insoluble residue, and hematite, goethite, muscovite and kaolinite as minor components.

\section{Micropaleontology}

Sample UP 4B was generally very poor in organic remains. It provided only two specimens of angiosperm pollen grains belonging to the family Myricaceae (Fig. 7A) which are likely Tertiary in age. Fossil pollen grains of Myricaceae are known from Tertiary to recent (Frederiksen 1996). Fossil angiosperm flowers have been found scarcely and therefore the identification of fossil angiosperm pollen (sporae dispersae) is mostly known from comparison with modern reference pollen slides. 

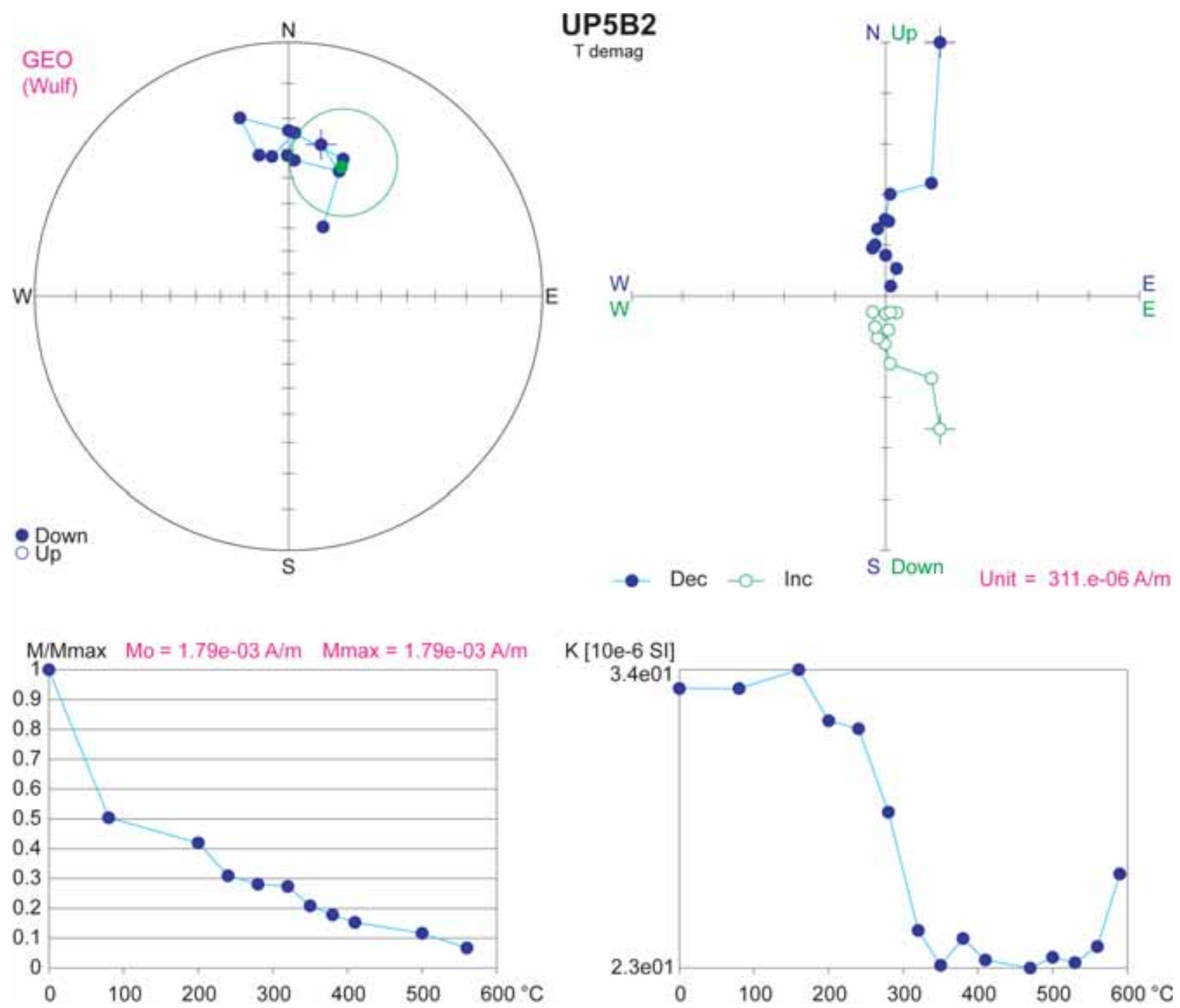

Figure 9. Results of progressive thermal demagnetization (TD) on sample UP 5B2 with normal paleomagnetic polarity. A stereographic projection of the remanent magnetization of a sample in the natural state (small cross across grey circle) and after TD. Zijderveld (1967) diagram - solid circles represent projection on the horizontal plane (XY); open circles represent projections on the north-south vertical plane (XZ). A graph of normalized values of the remanent magnetic moments versus TD fields. A graph of the normalized values of volume magnetic susceptibility (K) versus TD fields.

Chitinous mouthparts (“jaw apparatus") of marine annelid worms (polychaetes) called scolecodonts were found (one specimen only) along with the pollen grains and plant phytoclasts (Fig. 7C). Despite the fact that the inner part of a scolecodont is formed of $\mathrm{CaCO}_{3}$, a chitinous cover protects the carbonate (Colbath \& Larson 1980) during acid digestion of the sample with HF and $\mathrm{HCl}$ acids. In addition to these some phytoclast remains were found, including a portion of a vessel element with pitting, of what is likely a coniferous tracheid, as well as another plant phytoclast (Fig. 7B, D, E). Several additional highly corroded, undeterminable organic-walled microfossils were also found.

\section{Paleomagnetic properties of studied samples}

AF demagnetization through 12 fields was applied to 5 pilot specimens, and typical results (sample UP6) are reported in Fig. 8. An isothermal remanent magnetization (IRM) was acquired progressively using a Magnetic Measurements MMPM10 pulse magnetizer in fields up to $1 \mathrm{~T}$. The acquired IRM was measured after each imparted field with an Agico JR-5 spinner magnetometer. The acquisition of IRM showed that sample UP6 reached magnetic saturation of more than 1,000 mT. The curve of AF demagnetization (up to $100 \mathrm{mT}$ ) after saturation does not intersect the IRM curve. These data demonstrate that some of the magnetic particles display a high magnetic hardness. 

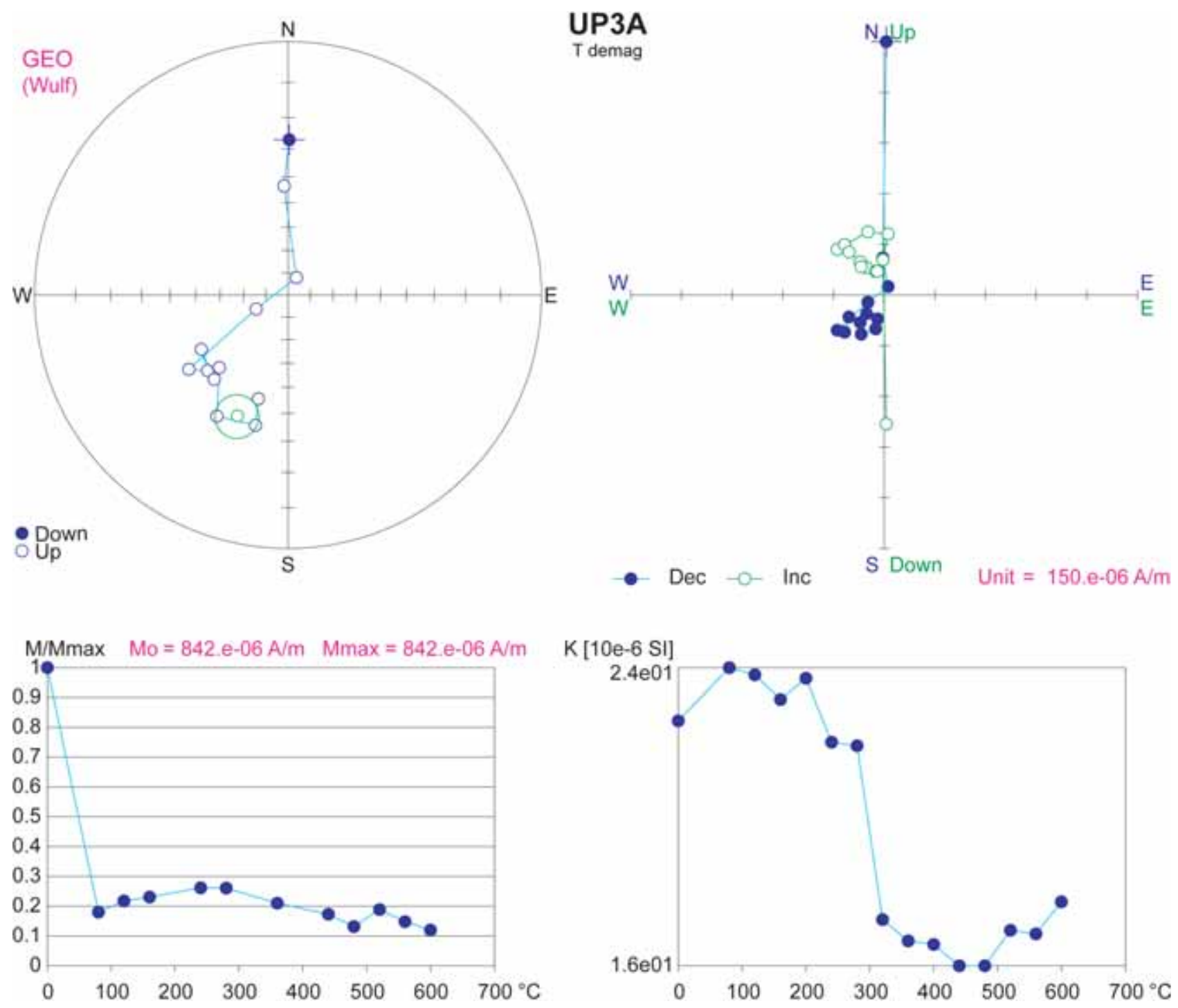

Figure 10. Results of progressive thermal demagnetization of sample (UP 3A) with reverse paleomagnetic polarity. See caption for Fig. 9.

The remaining 17 specimens were subjected to progressive thermal demagnetization to $600^{\circ} \mathrm{C}$. A multi-component analysis was applied to each sample and revealed two to three RM components (e.g., Figs 9, 10). The first component is undoubtedly of viscous origin and can be demagnetized within the temperature range of 20 to 80 (120) ${ }^{\circ} \mathrm{C}$. The second low-temperature component (LTC) is secondary, and displays harder magnetic properties. It is destroyed within the temperature range of 80 to 240 (200) ${ }^{\circ} \mathrm{C}$. The third, characteristic high-temperature stable component $(\mathrm{ChRM})$ is isolated within the temperature range of 280 to $520(560){ }^{\circ} \mathrm{C}$. Most samples exhibited low NRM and MS values. NRM values for all sedimentary rocks varied between 0.25 and $2.375 \mathrm{~mA} . \mathrm{m}^{-1}$ and respective MS values range from 5.1 to $55.1 \times 10^{-6} \mathrm{SI}$ units. The obtained data are contained in Tables 1 and 2.

The principal carriers for each component of magnetiza- tion were found to be goethite (viscous component of magnetization), and $\mathrm{Fe}$-oxides (probably magnetite with a wider spectrum of blocking temperatures, within $400-580{ }^{\circ} \mathrm{C}$ ). Hematite is most probably contained in some samples from UP (the blocking temperature is around $660^{\circ} \mathrm{C}$ ). In general, ferrimagnetic concentrations are low in the sedimentary rocks sampled at both localities.

\section{Stable isotopes}

Stable isotope data were collected from 15 samples (1 from KL and 14 from UP), ten of which represent a detailed $35 \mathrm{~mm}$ long profile across alternating coarse- and finegrained carbonates within sample UP4A (see Fig. 4). All stable isotope data are plotted in Fig. 11 together with data for Silurian and Devonian limestones of the Prague Syn- 
Table 1. Bohemian Karst, Únorová propast: basic paleomagnetic data for samples with normal polarity.

\begin{tabular}{|c|c|c|c|c|c|c|c|c|}
\hline \multirow[t]{2}{*}{ No. sample } & \multirow[t]{2}{*}{ Locality } & \multicolumn{2}{|c|}{ Location } & \multicolumn{2}{|c|}{ Characteristic component RM } & \multicolumn{2}{|c|}{ Virtual pole position } & \multirow{2}{*}{$\begin{array}{l}\text { Palaeolatitude } \\
\qquad \varphi_{\mathrm{m}}\left[^{\circ}\right] \mathrm{N}\end{array}$} \\
\hline & & Lat. $\varphi\left[{ }^{\circ}\right] \mathrm{N}$ & Long. $\Lambda\left[{ }^{\circ}\right] \mathrm{E}$ & Decl. $\left[{ }^{\circ}\right]$ & Incl. $\left[{ }^{\circ}\right]$ & $\begin{array}{l}\text { Palaeolat. } \\
\varphi_{\mathrm{p}}\left[^{\circ}\right] \mathrm{N}\end{array}$ & $\begin{array}{c}\text { Palaeolong. } \\
\Lambda_{\mathrm{p}}\left[^{\circ}\right] \mathrm{E}\end{array}$ & \\
\hline UP4B4 & Únorová propast & 49.9555 & 14.1888 & 13.7 & 32.1 & 55.64 & 170.58 & 17.41 \\
\hline UP5B2 & Únorová propast & 49.9555 & 14.1888 & 22.4 & 32.4 & 52.99 & 157.08 & 17.60 \\
\hline UP5B3 & Únorová propast & 49.9555 & 14.1888 & 14.4 & 32.8 & 55.89 & 169.22 & 17.86 \\
\hline UP5B4 & Únorová propast & 49.9555 & 14.1888 & 11.3 & 31.0 & 55.54 & 174.82 & 16.72 \\
\hline
\end{tabular}

Table 2. Bohemian Karst, Únorová propast: basic paleomagnetic data for samples with reverse polarity.

\begin{tabular}{|c|c|c|c|c|c|c|c|c|}
\hline \multirow[t]{2}{*}{ No. sample } & \multirow[t]{2}{*}{ Locality } & \multicolumn{2}{|c|}{ Location } & \multicolumn{2}{|c|}{$\begin{array}{c}\text { Characteristic component } \\
\text { RM }\end{array}$} & \multicolumn{2}{|c|}{ Virtual pole position } & \multirow{2}{*}{$\begin{array}{l}\text { Palaeolatitude } \\
\varphi_{\mathrm{m}}\left[^{\circ}\right] \mathrm{N}\end{array}$} \\
\hline & & Lat. $\varphi\left[{ }^{\circ}\right] \mathrm{N}$ & Long. $\Lambda\left[^{\circ}\right] \mathrm{E}$ & Decl. $\left[{ }^{\circ}\right]$ & Incl. $\left[{ }^{\circ}\right]$ & $\begin{array}{l}\text { Palaeolat. } \\
\varphi_{\mathrm{p}}\left[^{\circ}\right] \mathrm{N}\end{array}$ & $\begin{array}{c}\text { Palaeolong. } \\
\Lambda_{\mathrm{p}}\left[^{\circ}\right] \mathrm{E}\end{array}$ & \\
\hline UP3A & Únorová propast & 49.9555 & 14.1888 & 202.8 & -35.3 & 54.55 & 155.15 & 19.49 \\
\hline UP4A1 & Únorová propast & 49.9555 & 14.1888 & 192.4 & -39.9 & 61.05 & 170.03 & 22.69 \\
\hline UP4A2 & Únorová propast & 49.9555 & 14.1888 & 224.9 & -31.0 & 41.05 & 130.50 & 16.72 \\
\hline UP4A3 & Únorová propast & 49.9555 & 14.1888 & 210.3 & -48.9 & 59.61 & 134.27 & 29.82 \\
\hline UP4B1 & Únorová propast & 49.9555 & 14.1888 & 205.2 & -21.9 & 46.19 & 157.11 & 11.36 \\
\hline UP4B2 & Únorová propast & 49.9555 & 14.1888 & 189.4 & -40.1 & 61.89 & 175.56 & 22.83 \\
\hline UP4C1 & Únorová propast & 49.9555 & 14.1888 & 214.5 & -30.4 & 46.41 & 142.17 & 16.35 \\
\hline UP4C2 & Únorová propast & 49.9555 & 14.1888 & 197.2 & -24.9 & 50.51 & 167.25 & 13.07 \\
\hline UP5A1 & Únorová propast & 49.9555 & 14.1888 & 193.0 & -39.2 & 60.41 & 169.24 & 22.19 \\
\hline UP4B3 & Únorová propast & 49.9555 & 14.1888 & 206.1 & -39.6 & 55.74 & 147.95 & 22.47 \\
\hline
\end{tabular}

form, diagenetic infillings in Devonian limestones, and common speleothems of the Koněprusy Caves (comparison data after Žák et al. 1987 and Hladíková et al. 1989, 1997). Stable isotope data are also presented in Table 3. A profile extended across the cyclic layering of studied paleokarst sedimentary rock shows regular opposed changes of the $\delta^{13} \mathrm{C}$ and $\delta^{18} \mathrm{O}$ values (Fig. 12).

\section{Discussion}

The described paleokarst carbonate sedimentary rocks represent a new rock type for the Bohemian Karst region. Paleokarst features are quite common in the region (Bosák 1985, 1997, 1998), nevertheless, the sedimentary infilling of these cavities and depressions is dominated by clastic unconsolidated sediments (clays, sands, gravel), and not by carbonate. Secondary cave carbonate deposits of Cenozoic age (speleothems) are common in the area as well, but they are not of red color, usually show typical lamination, and exhibit quite different $\delta^{13} \mathrm{C}$ and $\delta^{18} \mathrm{O}$ data than the studied sedimentary rocks. Neptunian dikes well known from the area (Chlupáč 1996) typically show Devonian marine infilling, while the studied sediments are significantly younger and clearly postdate the Variscan folding. No similar type of red, well lithified, recrystallized layered limestone with a clastic component have previously been described and studied in this region.

\section{Petrography}

The studied limestone has undergone at least two recrystallization phases. The older phase represents the recrystallization of the original rock, which resulted in sparitic mosaic with pseudo-brecciated textures as well as ghosts after recrystallized fossils (resembling ostracodes) and some larger calcite rhombohedra. The younger phase is likely a result of a combination of weathering (karstification) as well as the formation of corrosional vugs and calcite veinlets. The original rock texture, with the exception of lithoclasts, has been completely hidden by both of these recrystallization phases. Sample UP7, composed of lithoclasts (sedimentary breccia), originated after the first recrystallization phase when some erosional/tectonic events decomposed and redeposited the original rock of the first recrystallization phase along with fragments of Devonian sedimentary rocks.

The Fe minerals in the studied rocks (mostly hematite and goethite, based on RTG determination) could originate by several processes. Either the grains of Fe secondary minerals were washed from the deeply weathered surface into 


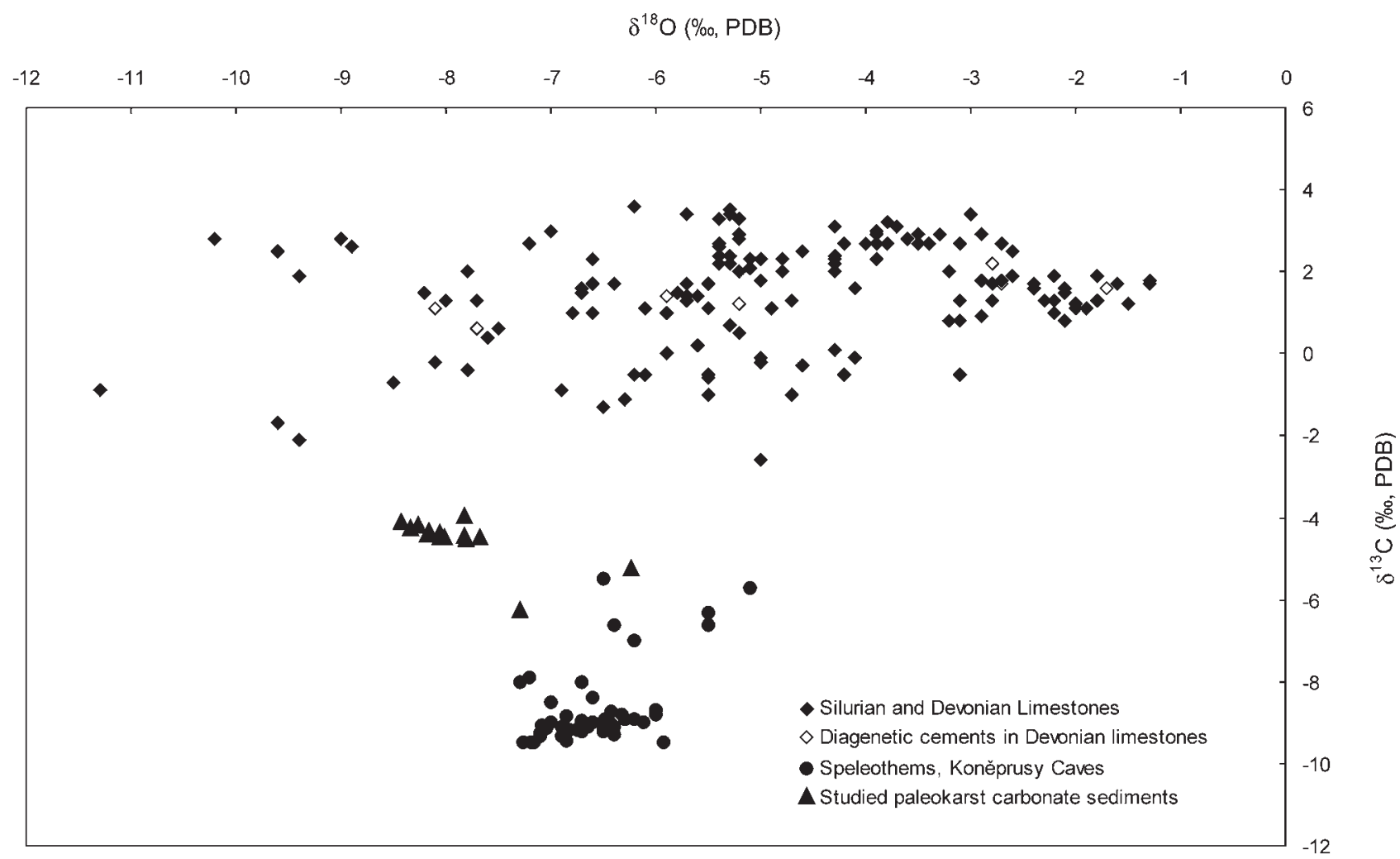

Figure 11. Carbonate $\delta^{13} \mathrm{C}$ and $\delta^{18} \mathrm{O}$ isotopic data of paleokarst limestone from Únorová propast Chasm and Kruhový lom Quarry. Comparison data for Silurian and Devonian limestones, diagenetic cements, and cave speleothems are from Žák et al. (1987), and Hladíková et al. (1989, 1997).

the subsurface cavities, where they were incorporated into the studied carbonate sedimentary rocks, or part of the Fe secondaries could also have been formed directly within the paleokarst cavities, as a result of oxidative decomposition of pyrite contained as an accessory in the Devonian limestones. The position/s of the mineral grains could have been partly modified during rock recrystallization. Nevertheless, the original paleomagnetic record was not completely destroyed, since samples located vertically only $4 \mathrm{~cm}$ apart within the sedimentary layers revealed normal and reversed orientation of the ChRM component. In case that the original signal would have been completely lost during recrystallization, such circumstances could not have survived.

\section{Micropaleontology}

Sample UP4B contained no plant microfossils which could confirm the Triassic age indicated by paleomagnetic methods (see below). Generally, the quantity of obtained microfossils was very low. Some younger plant and faunal remains, such as angiosperm pollen grains belonging to the Myricaceae (Fig. 7A) were found and are likely Tertiary in age. The sedimentary rocks contained some cavities (cracks) filled by a younger carbonate and some porosity (see the Petrography section). The redeposited plant and faunal remains might have originated from these younger paleokarst fillings and pores. The only marine influence within the sample is indicated by the occurrence of scolecodont which was probably redeposited from some other rocks. Scolecodonts are usually brown or black in color but the specimen found in sample UP4B is pale, probably indicating limited diagenetic changes. These annelid jaw elements have been found in rocks as old as Early Ordovician (Arenigian) and continue to the Recent. They are most abundant in shallow water marly limestones and shales and are resistant to chemical degradation (Szaniawski 1996). During the Upper Cretaceous the studied area was covered by shallow epicontinental sea. The scolecodont specimen found could have been washed into the UP cavity during this period. We interpret all the micropaleontological finds as post-depositional sample contamination. The studied sedimentary rocks are locally porous and were located in a zone of further karstification, especially during Late Cretaceous, and Cenozoic.

\section{Paleogeographic interpretation of paleomagnetic results}

Selected measurement results of the TD from UP are presented on Figs 9 and 10, including samples with normal 


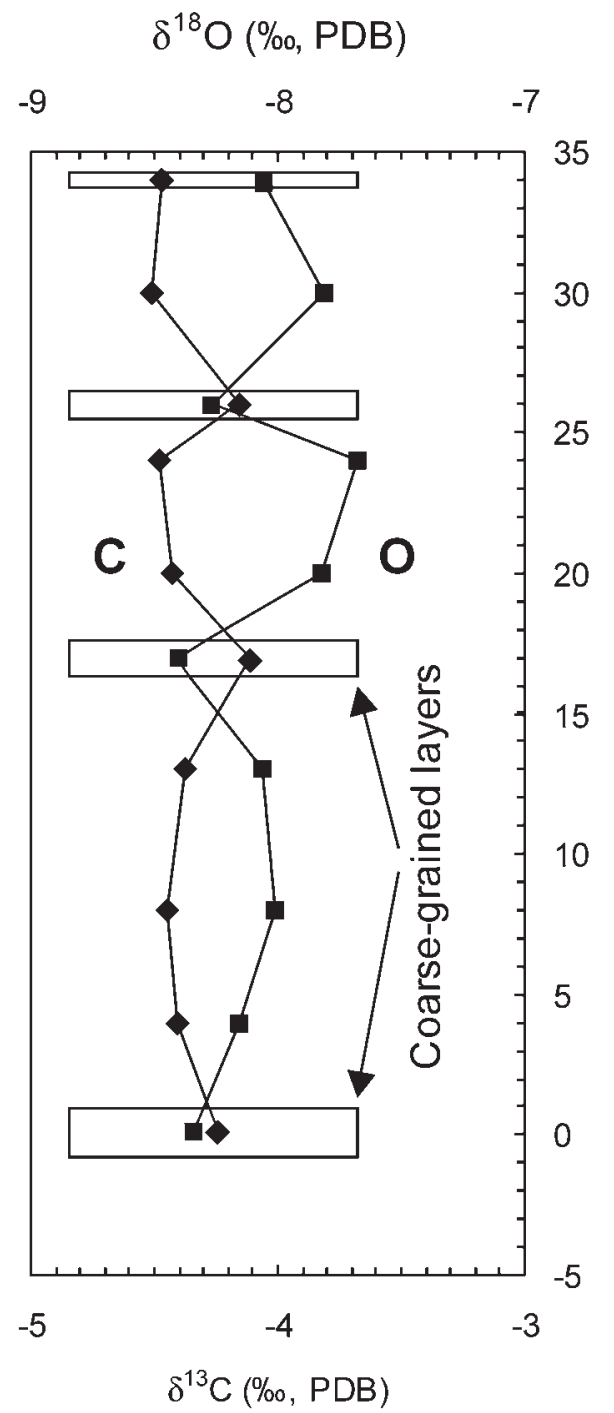

Figure 12. Stable isotope profiles across the alternating coarse- and fine-grained paleokarst carbonate (compare to Fig. 4). The coarse-grained layers are shown as rectangles. Widths of these rectangles indicate thickness of the coarse-grained layers. The $\delta^{18} \mathrm{O}$ values are shown by squares; $\delta^{13} \mathrm{C}$ values by diamonds.

(UP 5B2) and reversed paleomagnetic polarity (UP 3A). The figures also include diagrams of volume magnetic susceptibility $(\mathrm{K})$ versus laboratory temperature. Although increases in $\mathrm{K}$ occurred in several samples at temperatures above $500{ }^{\circ} \mathrm{C}$ (with respect to high magnetic vacuum in the MAVACS demagnetizer), this phase change was not manifested in the normalized $\mathrm{M} / \mathrm{M}_{\max }$ values and the unblocking temperatures were determined with the same precision as in magnetically stable samples.

One sample from KL gave a ChRM direction of $\mathrm{D}=$ $175^{\circ}, \mathrm{I}=-29^{\circ}$ and this direction was not included in statistical mean directions. Further sampling at the KL locality was not possible since the paleokarst filling was destroyed by the quarry. Directions of the ChRM (HTC)
Table 3. Stable isotope data.

\begin{tabular}{|c|c|c|}
\hline Locality, sample number, description & $\begin{array}{c}\delta^{13} \mathrm{C} \\
{[\% o, \mathrm{PDB}]}\end{array}$ & $\begin{array}{c}\delta^{18} \mathrm{O} \\
{[\% o, \mathrm{PDB}]}\end{array}$ \\
\hline Únorová propast, UP-1 (old) & -3.96 & -7.83 \\
\hline Únorová propast, UP-1 & -4.31 & -8.16 \\
\hline Únorová propast, UP 2 & -6.23 & -7.29 \\
\hline Únorová propast, UP 3 & -4.40 & -8.17 \\
\hline Kruhový lom, KL-1 & -5.22 & -6.24 \\
\hline $\begin{array}{l}\text { Únorová propast, UP 4A-profile, base, } \\
\text { coarse-grained layer }\end{array}$ & -4.24 & -8.34 \\
\hline $\begin{array}{l}\text { Únorová propast, UP 4A-profile, } 4 \mathrm{~mm} \\
\text { from base, fine-grained layer }\end{array}$ & -4.41 & -8.16 \\
\hline $\begin{array}{l}\text { Únorová propast, UP 4A-profile, } 8 \mathrm{~mm} \\
\text { from base, fine-grained layer }\end{array}$ & -4.45 & -8.01 \\
\hline $\begin{array}{l}\text { Únorová propast, UP 4A-profile, } 13 \mathrm{~mm} \\
\text { from base, fine-grained layer }\end{array}$ & -4.37 & -8.06 \\
\hline $\begin{array}{l}\text { Únorová propast, UP 4A-profile, } 17 \mathrm{~mm} \\
\text { from base, coarse-grained layer }\end{array}$ & -4.11 & -8.42 \\
\hline $\begin{array}{l}\text { Únorová propast, UP 4A-profile, } 20 \mathrm{~mm} \\
\text { from base, fine-grained layer }\end{array}$ & -4.43 & -7.82 \\
\hline $\begin{array}{l}\text { Únorová propast, UP 4A-profile, } 24 \mathrm{~mm} \\
\text { from base, fine-grained layer }\end{array}$ & -4.48 & -7.68 \\
\hline $\begin{array}{l}\text { Únorová propast, UP 4A-profile, } 26 \mathrm{~mm} \\
\text { from base, coarse-grained layer }\end{array}$ & -4.16 & -8.26 \\
\hline $\begin{array}{l}\text { Únorová propast, UP 4A-profile, } 30 \mathrm{~mm} \\
\text { from base, fine-grained layer }\end{array}$ & -4.51 & -7.81 \\
\hline $\begin{array}{l}\text { Únorová propast, UP 4A-profile, } 34 \mathrm{~mm} \\
\text { from base, coarse-grained layer }\end{array}$ & -4.47 & -8.06 \\
\hline
\end{tabular}

with $\mathrm{N}$ and $\mathrm{R}$ polarities from UP are shown in Fig. 13. Specimens UP 4B2 and UP 4B4 from sample UP 4B yielded ChRM components with both $\mathrm{N}$ and $\mathrm{R}$ polarity, indicating a change in polarity over an vertical interval of $4 \mathrm{~cm}$. Tables 1 and 2 summarize the results of the normal and reversed directions of the ChRM, virtual pole positions and paleolatitudes. The mean paleomagnetic directions and virtual pole positions calculated for sample groups displaying normal and reverse polarities are given in Table 4. This table also presents paleomagnetic pole positions calculated for all samples from UP where reverse paleomagnetic directions were converted into normal directions. The difference between the mean normal $\left(\mathrm{I}=32.1^{\circ}\right)$ and reversed $\left(\mathrm{I}=-35.6^{\circ}\right)$ inclinations is smaller than the semi-angle of confidence (see $\alpha_{95}{ }^{\circ}$ in Table 4).

In order to make paleogeographic interpretations from these data it was necessary to extrapolate the area of the Bohemian Massif (locality UP) to the larger data sets from the European continent for Middle Triassic to Middle Devonian (Krs \& Pruner 1995, Krs et al. 2001), and to data from Besse \& Courtillot (1991) for the period from 4 Ma to $195 \mathrm{Ma}$. For the Middle and Early Triassic periods the orientation of paleomeridians (the Russian Platform, Fennoscandia and Western Europe) is in mutual agreement 
among these data sets with the geocentric dipole field. The paleomagnetic pole position $\left(54.8^{\circ} \mathrm{N}, 157.8^{\circ} \mathrm{E}, \alpha_{95} 3^{\circ}\right)$ calculated for UP is very close to pole positions for the Middle $\left(55.1^{\circ} \mathrm{N}, 140.6^{\circ} \mathrm{E}, \alpha_{95} 5.8^{\circ}\right)$ or Early Triassic $\left(48.5^{\circ} \mathrm{N}, 162.1^{\circ} \mathrm{E}, \alpha_{95} 5.3^{\circ}\right)$ inferred for the European Plate (see Fig. 14). The calculated paleolatitude for UP is $19.8^{\circ} \mathrm{N}$, which corresponds to a paleolatitudinal drift of $30.2^{\circ}\left( \pm 3^{\circ}\right)$ north from Triassic times to the present. The paleolatitudes are also in agreement for all territories to the north of the Alpine tectonic belt.

\section{Stable isotopes}

The carbonate $\delta^{13} \mathrm{C}$ and $\delta^{18} \mathrm{O}$ data from the UP and KL localities extend over a limited area in Fig. 11. This field is quite different from those of Silurian and Devonian limestones of the Prague Synform. This is also different from diagenetic carbonate types within the Devonian limestones and from common types of Cenozoic cave speleothems from this region. Lithological and isotopic similarities for both localities (UP and KL) as well as the occurrence of this type of paleokarst filling in structures of similar direction indicate that UP and KL rocks were likely deposited under similar conditions. Unfortunately, the KL locality was destroyed by quarrying before a detailed study was possible.

The $\delta^{13} \mathrm{C}$ data of the studied sedimentary rocks between -4.0 and $-6.2 \%$ (PDB) do not correspond to a range typical for Phanerozoic unmetamorphosed marine limestones, which have $\delta^{13} \mathrm{C}$ data between -2 and $+6 \%$ (Veizer et al. 1999). It is clear therefore that the studied new type of paleokarstic limestones were deposited in a freshwater environment. This is in agreement with paleogeographic conditions of this part of the Bohemian Massif, which was non-marine during the Triassic (Chlupáč et al. 2002). A hot, arid climate was present from the Permian to the Triassic, nevertheless shallow seas around the Vindelic elevation could partly reduce the aridity (Chlupáč et al. 2002). Deposition likely occurred deep below the surface within a cavity filled with groundwater.

These carbonate sedimentary rocks display fairly regular cyclicity in some sections, with alternating coarse- and fine-grained layers (see Fig. 4). Regularly opposed changes in $\delta^{13} \mathrm{C}$ and $\delta^{18} \mathrm{O}$ in the stable isotope profiles (Fig. 12) can not be the result of repeated water evaporation nor of varying amounts of clastic carbonate admixture derived from Devonian limestone, because both of these processes would increase $\delta^{13} \mathrm{C}$ and $\delta^{18} \mathrm{O}$ values. Instead, we interpret the stable isotope record as reflecting primary oscillations of depositional conditions, likely changes of surface precipitation quantity and/or depositional temperature changes in the UP Chasm. As indicated by the field relationships (see vertical sections of the

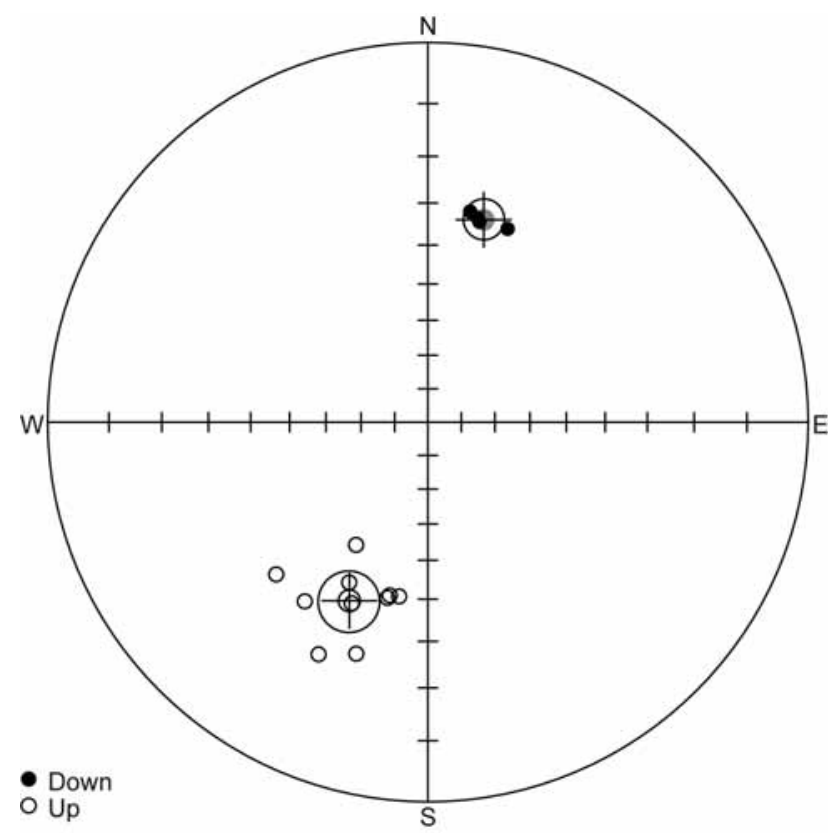

Figure 13. Bohemian Karst, Únorová propast (UP). Directions of C-components of remanence. Normal directions are marked by small full circles. Reverse directions are represented by small empty circles. The mean directions are marked by great circles and the $95 \%$ confidence circle is circumscribed about the mean direction.

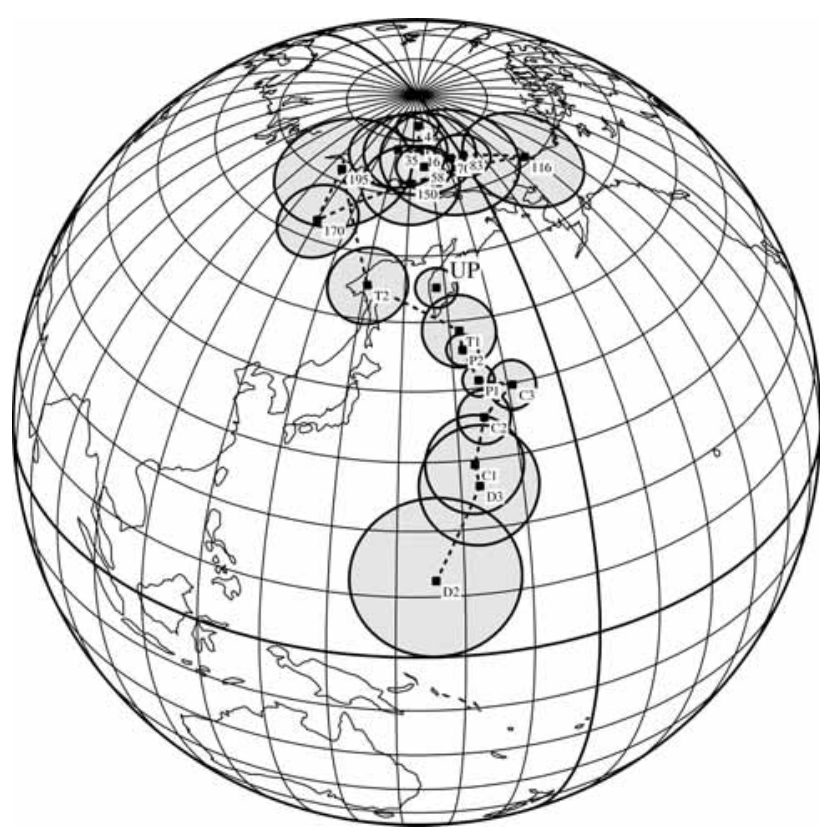

Figure 14. Paleomagnetic pole position of the Bohemian Karst, Únorová propast (UP). The Apparent Polar Wander Paths (APWP) for a stable Europe is based on data from Besse \& Courtillot (1991) for the period from 4 to $195 \mathrm{Ma}$, and from Krs \& Pruner (1995) for the Middle Triassic to Middle Devonian period. Mean pole positions: T2, T1 - Middle, Early Triassic; P2, P1 - Late, Early Permian; C3, C2, C1 - Late, Middle, Early Carboniferous; D3, D2 - Late, Middle Devonian. Mean pole positions and confidence circles calculated at the $95 \%$ probability level according to Fisher (1953). 
Table 4. Bohemian Karst, Únorová propast: paleomagnetic pole positions. Note: Pole positions were calculated for samples with normal polarity; reverse polarized samples were transformed into normally polarized samples.

\begin{tabular}{|c|c|c|c|c|c|c|c|c|c|c|c|c|}
\hline \multirow{2}{*}{ Locality } & \multirow{2}{*}{ Polarity } & \multicolumn{2}{|c|}{ Location } & \multicolumn{2}{|c|}{$\begin{array}{c}\text { Mean paleomagnetic } \\
\text { directions }\end{array}$} & \multirow[t]{2}{*}{$\begin{array}{c}\alpha_{95} \\
{\left[{ }^{\circ}\right]}\end{array}$} & \multirow[t]{2}{*}{$\mathrm{k}$} & \multirow[t]{2}{*}{$\mathrm{n}$} & \multicolumn{2}{|c|}{$\begin{array}{c}\text { Paleomagnetic pole } \\
\text { positions }\end{array}$} & \multicolumn{2}{|c|}{$\begin{array}{l}\text { Ovals of } \\
\text { confidence }\end{array}$} \\
\hline & & $\begin{array}{l}\text { Lat. } \varphi \\
{\left[{ }^{\circ}\right] \mathrm{N}}\end{array}$ & $\begin{array}{c}\text { Long. } \Lambda \\
{\left[{ }^{\circ}\right] \mathrm{E}}\end{array}$ & $\begin{array}{c}\text { Decl. } \\
{\left[{ }^{\circ}\right]}\end{array}$ & $\begin{array}{c}\text { Incl. } \\
{\left[{ }^{\circ}\right]}\end{array}$ & & & & $\begin{array}{l}\text { Paleolat. } \\
\varphi_{\mathrm{p}}\left[^{\circ}\right] \mathrm{N}\end{array}$ & $\begin{array}{l}\text { Paleolong. } \\
\Lambda_{\mathrm{p}}\left[{ }^{\circ}\right] \mathrm{E}\end{array}$ & $\begin{array}{l}\delta_{\mathrm{m}} \\
{\left[{ }^{\circ}\right]}\end{array}$ & $\begin{array}{l}\delta_{\mathrm{p}} \\
{\left[{ }^{\circ}\right]}\end{array}$ \\
\hline Únorová propast & $\mathrm{N}$ & 49.9555 & 14.1888 & 15.4 & 32.1 & 3.6 & 380.7 & 4 & 55.2 & 167.8 & 3.0 & 5.3 \\
\hline Únorová propast & $\mathrm{R}$ & 49.9555 & 14.1888 & 203.7 & -35.6 & 6.6 & 44.7 & 10 & 54.3 & 153.7 & 4.9 & 8.5 \\
\hline Únorová propast & $\mathrm{N}+\mathrm{R}^{*}$ & 49.9555 & 14.1888 & 21.3 & 34.6 & 5.0 & 55.3 & 14 & 54.8 & 157.8 & 3.6 & 6.2 \\
\hline
\end{tabular}

UP Chasm, Fig. 3), the depositional environment was located in a deep narrow cavity at least several tens of meters below the surface. Such environment was most probably not significantly influenced by water evaporation, as indicated also by the stable isotope data. Carbonate deposition during water evaporation is due to kinetic isotope effects characterized by increases of both $\delta^{13} \mathrm{C}$ and $\delta^{18} \mathrm{O}$ data (Hendy 1971, Mickler et al. 2006), which were not observed in the studied samples.

Depositional and climatic conditions during formation of the studied paleokarst carbonate sedimentary rocks were clearly quite different from conditions in the Quaternary, as evidenced by the different fields of data for studied paleokarst limestone and Quaternary speleothems in Fig. 11. Temperature at the depositional site during the formation of the studied red limestone was most probably higher than is the present-day temperature of the UP, and could have been further increased by deeper (thermal) groundwater circulation.

\section{Age and regional relationships of the paleokarst fillings}

Until this point the Triassic period was not considered a suitable period for karstification with respect to desert climate in the area of Bohemian Massif (Bosák 1985, 1997, 1998). The only paper considering sedimentation of talus material in paleo-depressions in the area during the Permian-Triassic (Turnovec \& Pechová 1980) did not present supporting evidence. Sedimentary infillings of some structures in the Koněprusy area (drillings V304, V306) were conjectured as being similar to Permian-Carboniferous sediments by K. Schmid (in Ovčarov et al. 1972) but also without any evidence. The paleomagnetic results described herein represent the first indication of probable Triassic sedimentation within the central part of the Bohemian Massif.

These paleokarst carbonates evolved within cavities and on the surfaces of breccias filling fault zones. Locally, breccia evolution is expressed as a gradual decrease in rock fragment diameter down to sandy limestone. At other sites within the same locality the breccias clearly overlie the red paleokarst sedimentary rocks (see Fig. 2). These field ob- servations indicate that the formation of breccia, and of the studied paleokarst limestones were closely related. If the paleomagnetic results correspond to the real age of the rocks, this indicates that the NW trending, steeply dipping faults, which host the studied paleokarst filling, were active during the Late Permian to Triassic. This is in agreement with fault activity in the well-known Příbram Ore Region, located about $25 \mathrm{~km} \mathrm{SSW}$ of the studied area, where numerous carbonate hydrothermal veins with similar direction bear uranium mineralization, which has been repeatedly dated between 265 and $275 \mathrm{Ma}$ (Late Permian) using U/Pb dating (reviewed by Vlašímský et al. 1995). The fault (and vein) strike in the Príbram Ore Region, and of the faults hosting the studied paleokarst sedimentary rocks in the Bohemian Karst are all quite similar. This agreement in fault direction represents further supporting evidence for Late Permian to Triassic tectonic activity on NW-SE oriented faults in this part of Bohemian Massif.

\section{Conclusions}

A new type of carbonate paleokarst sedimentary rocks has been found at two localities in the Czech Republic's Bohemian Karst. Field observations indicate that these limestones, which are seen as infilling paleokarst cavities, are quite different from the usual Cretaceous, Tertiary and Quaternary sediments of this karst region as well as from common Cenozoic cave speleothems. Field relationships, petrology and geochemistry of both localities are similar and these sedimentary rocks clearly postdate the Variscan folding. In both cases the carbonate paleokarst filling with horizontal or slightly inclined layering was formed within cavities of karstified fault zones of NW-SE direction deep below the original surface. The well-layered coarse crystalline reddish limestones are characterized by highly irregularly recrystallized sparite with impurities at grain boundaries (mostly secondary Fe minerals). Carbonate $\delta^{13} \mathrm{C}$ and $\delta^{18} \mathrm{O}$ isotopic data of the paleokarstic sedimentary rocks ( $\delta^{13} \mathrm{C}$ from -4.0 to $-6.2 \%$, $\delta^{18} \mathrm{O}$ from -6.2 to $-8.4 \%$ PDB $)$ are quite different from both the marine limestone and the secondary cave carbonates, and indicate a non-marine depositional environment. The calculated paleomagnetic 
pole position for Únorová propast (UP) is very close to pole positions for the Middle or Early Triassic and the calculated paleolatitude also corresponds to a paleolatitudinal drift of $30.2^{\circ}\left( \pm 3^{\circ}\right)$ north from Triassic times to the present. However, the Triassic age indicated by the paleomagnetic study was not confirmed by plant microfossils in the sedimentary rocks, which suggest a Tertiary date. However, microfossils are very rare in the studied rocks and all finds are interpreted as post-depositional contamination. The one specimen of scolecodont found is interpreted as being redeposited from some (Cretaceous?) marine sediment. Some of the younger plant and faunal remains found, such as angiosperm pollen grain specimens belong to the Myricaceae family and are likely Tertiary in age. Based on the known range of the identifiable fossils, these plant microfossils are interpreted as having been transported into cracks and cavities of the studied sedimentary rocks during the Tertiary.

\section{Acknowledgments}

The paleokarst fillings described herein were discovered during the field survey for project GA ČR 205/02/0449; stable isotope analyses were performed as part of that same project. Our work was further supported by research program AV0Z30130516 of the Institute of Geology, AS CR, Prague. Paleomagnetic studies were part of projects IAA3013406 and IAA300130701. We would like to thank the mining company Lomy Mořina for permission to work in the quarries and for technical assistance. We appreciated O. Jäger's (Správa CHKO Český kras) assistance with sampling, sample transportation, and field photo documentation. The authors are also grateful to W.J. DeBoer for language correction of the manuscript. The manuscript was significantly improved thanks to comments of three reviewers and of the Bulletin of Geosciences editors J. Hladil and S. Turner.

\section{References}

Besse, J. \& Courtillot, V. 1991. Revised and synthetic apparent polar wander paths of the African, Eurasian, North American and Indian plates, and true polar wander since $200 \mathrm{Ma}$. Journal of Geophysical Research 96, 4029-4050.

BosÁK, P. 1985. Periody a fáze krasovění v Českém krasu [Karstification periods and phases in the Bohemian Karst]. Český kras 11, 36-55.

BosÁk, P. 1997. Paleokarst of the Bohemian Massif in the Czech Republic: an overview and synthesis. International Journal of Speleology 24(1-4, 1995), 3-39.

BosÁK, P. 1998. Projevy předsvrchnokřídového krasovění (karbon-cenoman) v Barrandienu (Česká Republika) [Pre-Upper Cretaceous karstification (Carboniferous-Cenomanian) in the Barrandian (Czech Republic)]. Český kras 24, 56-59.

CHLuPÁČ, I. 1996. Neptunian dykes in the Koněprusy Devonian:
Geological and paleontological observations. Bulletin of the Czech Geological Survey 71(3), 193-208.

Chlupáč, I., HaVlíčEK, V., KŘíž, J., KuKal, Z. \& ŠTORCh, P. 1998. Palaeozoic of the Barrandian (Cambrian to Devonian). 185 pp. Czech Geological Survey, Prague.

Chlupáč, I., Brzobohatý, R., Kovanda, J. \& Stráník, Z. 2002. Geologická minulost České republiky. 436 pp. Academia, Praha.

Colbath, G.K. \& Larson, S.K. 1980. On the chemical composition of fossil polychaete jaws. Journal of Paleontology 54(2), 485-488.

FISHER, R. 1953. Dispersion on a sphere. Proceedings of the Royal Society of London, Series A 217, 295-305.

FrederiKSEN, N.O. 1996. Chapter 20F. Uppermost Cretaceous and Tertiary spore/pollen biostratigraphy, 831-841. In JANsonius, J. \& MCGREGor, D.C. (eds) Palynology: principles and applications, Vol. 2. American Association of Stratigraphic Palynologists Foundation, Salt Lake City.

HaVlíčEK, D., ŠUba, J., URBAn, J., VAŠÁK, K. \& ZelenKa, A. 1980. Únorová propast - nová propast v Českém krasu. Československý kras 31, 106-107.

HAVlíČEK, D. \& URBAN, J. 1979. Nové objevy v Únorové propasti v Českém krasu. Stalagmit 3-4, 3.

HAVLÍČEK, D. \& URBAN, J. 1984. Krasové jevy ve štolách severozápadní stěny Shniloušáku v Českém krasu (Karst phenomena in the north-west wall of the Shniloušák Quarry, Bohemian Karst). Československý kras 34, 15-22.

HENDY, C.H. 1971. The isotopic geochemistry of speleothems-I. The calculation of effects of different modes of formation on the isotopic composition of speleothems and their applicability as paleoclimatic indicators. Geochimica et Cosmochimica Acta 35, 801-824.

HLadíKovÁ, J., MrÁZeK, P. \& ŽÁK, K. 1989. Izotopické složení uhlíku a kyslíku v karbonátových horninách Čech a Moravy. Unpublished research report, Czech Geological Survey, Praha.

Hladíková, J., HLAdil, J. \& KŘíBeK, B. 1997. Carbon and oxygen isotope record across Pridoli to Givetian stage boundaries in the Barrandian basin (Czech Republic). Palaeogeography Palaeoclimatology Palaeoecology 132, 225-241.

HovorKa, J. 1982. Speleopotápěčský průzkum Únorové propasti $v$ roce 1981. Unpublished report, Archive of the Czech Speleological Society, Praha.

Hrouda, F., ChlupÁčová, M. \& PoKorný, J. 2006. Low-field variation of magnetic susceptibility measured by the KLY-4S Kappabridge and KLF-4A magnetic susceptibility meter: Accuracy and interpretation programme. Studia geophysica and geodaetica 50(2), 283-299.

JELínEK, V. 1966. A high sensitivity spinner magnetometer. Studia geophysica et geodaetica 10, 58-78.

JELÍNEK, V. 1973. Precision A.C. bridge set for measuring magnetic susceptibility and its anisotropy. Studia geophysica et geodaetica 17, 36-48.

KirschVinK, J.L. 1980. The least-squares line and plane and the analysis of palaeomagnetic data. Geophysical Journal of the Royal Astronomical Society 62(3), 699-718.

KolČAvA, M. 2004. Nový soupis krasových jevů skupiny 24 
v Českém krasu (New inventory of the karst phenomena of group 24 in the Bohemian Karst). Český kras 30, 4-44.

KrS, M. \& PrunER, P. 1995. Palaeomagnetism and palaeogeography of the Variscan formations of the Bohemian Massif, comparison with other European regions. Journal of the Czech Geological Society 40(1-2), 3-46.

Krs, M., Pruner, P. \& MAN, O. 2001. Tectonic and paleogeographic interpretation of the paleomagnetism of Variscan and pre-Variscan formations of the Bohemian Massif, with special reference to the Barrandian terrane. Tectonophysics 332, 93-114.

LySENKO, V. 1978. Soupis jeskyní Českého krasu - oblast 24 (Ameriky, Mořina, Bubovice) [Höhlenkataster des Böhmischen Karstes - Region 24 (Amerikas, Mořina, Bubovice)]. Český kras 3, 57-67.

MCCREA, J.M. 1950. On the isotopic chemistry of carbonates and a paleotemperature scale. Journal of Chemical Physics 18, 849-857.

Melichar, R. 2004. Tectonics of the Prague Synform: a hundred years of scientific discussion. Krystalinikum 30, 167-187.

MelichaR, R. \& HLadil, J. 1999. Resurrection of the Barrandian nappe structures (Central Bohemia). Geolines 8, 48-50.

MickLER, P.J., STERN, L.A. \& BANNER, J.L. 2006. Large kinetic isotope effects in modern speleothems. Geological Society of America Bulletin 118, 65-81.

OvČAROv, K. et al. 1972. Závěrečná zpráva. Vyhodnocení vápenických a cementářských surovin v západní části Barrandienu. 189 pp. 5111349 107. Unpublished report, Geoindustria, Praha.

PříHOdA, K., KRS, M., PeŠINA, B. \& BlÁHA, J. 1989. MAVACS a new system creating a nonmagnetic environment for palaeomagnetic studies, 223-250. In BANDA, E. (ed.) Paleomagnetismo - Palaeomagnetism Cuadernos de Geologia Iberica. CSIC, Madrid, 1988-1989.

SvobodA, J. \& PrantL, F. 1950. O stratigrafii a tektonice staršího paleozoika v okolí Kody u Srbska. Sborník Státního geologického ústavu Československé republiky, Oddíl geologický 17, 393-436.

Svoboda, J. \& PRANTL, F. 1955. O stratigrafii a tektonice staršího paleozoika v širším okolí Karlštejna. Sborník Ústředního ústavu geologického, Oddíl geologický 21(1), 519-596.
SzaniawSKI, H. 1996. Chapter 12. Scolecodonts, 337-354. In Jansonius, J. \& McGregor, D.C. (eds) Palynology: principles and applications, Vol. 1. American Association of Stratigraphic Palynologists Foundation, Salt Lake City.

TuRnOveC, I. 1980. K otázce stář́ krasových jevů Barrandienu. Český kras 5, 44-46.

TuRnovec, I. \& PeChovÁ, J. 1980. Ložisko jílů Zadní Kopanina. Geologický průzkum 22(3), 90-91.

Veizer, J., Ala, D., Azmy, K., Bruckschen, P., Buhl, D., Bruhn, F., Carden, G.A.F., Diener, A., Ebneth, S., GodDeris, Y., Jasper, T., Korte, G., Pawellek, F., Podlaha, O.G. \& STRAuss, H. $1999 .{ }^{87} \mathrm{Sr} /{ }^{86} \mathrm{Sr}, \delta^{13} \mathrm{C}$ and $\delta^{18} \mathrm{O}$ evolution of Phanerozoic seawater. Chemical Geology 161, 59-88.

VLAŠÍMSKÝ, P., ŽÁK, K., KomínEK, J. \& PATOČKA, F. 1995. Late Variscan hydrothermal uraninite-anthraxolite deposits of the Př́ibram ore region, Bohemian Massif: Geology and genetic features of the largest uranium vein-type deposits of the Czech Republic, 397-400. In PAšAvA, J., KŘíBEK, B. \& ŽÁK, K. (eds) Mineral Deposits: From Their Origin to Their Environmental Impacts. A.A. Balkema, Rotterdam.

Wood, G.D., Gabriel, A.M. \& Lawson, J.C. 1996. Chapter 3. Palynological techniques - processing and microscopy, 29-50. In Jansonius, J. \& McGregor, D.C. (eds) Palynology: principles and applications, Vol. 1. American Association of Stratigraphic Palynologists Foundation, Salt Lake City.

Žák, K., HLadíková, J., Lysenko, V. \& SlačíK, J. 1987. Izotopické složení uhlíku a kyslíku jeskynních sintrů, žilných kalcitů a sedimentárních vápenců z Českého krasu. [Carbon and oxygen isotopic composition of cave sinters, vein calcites and sedimentary carbonates from the Bohemian Karst.] Český kras 13, 5-28.

ZIJDERVELD, J.D.A. 1967. A.C. demagnetization of rocks: Analysis of results, 254-268. In Collinson, D.W, CREER, K.M. \& RunCORN, S.K. (eds) Methods in paleomagnetism. Elsevier, New York.

ŽIVOR, R., ŽÁK, K. \& JäGER, O. 2002. Zdenina jeskyně - nový objev v Kruhovém lomu u Srbska (Zdenina Cave - a new discovery in the Kruhový lom Quarry near Srbsko, Czech Karst). Český kras 28, 16-17. 